American Journal of Applied Sciences 6 (4): 576-581, 2009

ISSN 1546-9239

(C) 2009 Science Publications

\title{
Mineralogy and Chemistry of Coronadite from Middle Cambrian Manganese Deposits at Wadi Dana, Southern Jordan
}

\author{
${ }^{1}$ Ahmad Al-Malabeh and ${ }^{2}$ Tayel El-Hasan \\ ${ }^{1}$ Department of Earth and Environmental Sciences, Hashemite University, \\ Zarqa 13115, P. O. Box 150459, Jordan \\ ${ }^{2}$ Faculty of Science, Mu'tah University, 61710, P.O. Box (7), Al-Karak, Jordan
}

\begin{abstract}
Coronadite was reported from the upper-most horizons of the Middle Cambrian sediments at two locations in Wadi Dana, central Wadi Araba and Jordan. The unit is composed of dolomite, limestone and shale. Geochemical investigations show appreciable variations in $\mathrm{Mn}, \mathrm{Pb}, \mathrm{Fe}, \mathrm{K}$ and $\mathrm{Ba}$ contents in the coronadite between the two studied sites. $\mathrm{Pb}$ was found to increase downward in both sites in spite of the lateral distance between them. Fe does not vary vertically, but its concentration decreases eastward. This can be attributed to the nature and mobilization direction, duration of the process, as well as the mechanism of both $\mathrm{Fe}$ and $\mathrm{Pb}$ bearing solutions. Mineralogical analysis has revealed the presence of hollandite-coronadite, cryptomelane-coronadite and psilomelane-coronadite in solid solutions. These petrographical and geochemical characteristics of the coronadite-bearing samples indicated that they formed epigenetically.
\end{abstract}

Key words: Middle Cambrian, coronadite, epigenetic genesis, lateralization, solid solution

\section{INTRODUCTION}

Coronadite is a Pb-Mn hydrous oxide that belongs to the tetravalent Mn-oxide-rich mineral that belongs to cryptomelane group, which is usually associated with supergene manganese ores ${ }^{[1-3]}$. The tetravalent $\mathrm{Mn}-$ oxides indicating oxidizing conditions during formation ${ }^{[4]}$.However, coronadite is reported also to form during lateralization ${ }^{[5]}$. Ehrlich et al. ${ }^{[6]}$ found manganese nodules that were composed mainly of coronadite formed by epigenetic solution.

Coronadite is fairly rare mineral of the oxidation zone, is in most cases the product of simultaneous weathering of $\mathrm{Mn}$ and $\mathrm{Pb}$-minerals; $\mathrm{Pb}$-replacment deposits in Mn-rich limestones ${ }^{[2]}$. Originally discovered and described by ${ }^{[7]}$ on ore vein in the state of Arizona, USA. Later was discovered associated with cryptomelane, hollandite, limonite, quartz and kaolinite in Morroco ${ }^{[8]}$.

Manganese deposits crop out in central Wadi Araba, mainly at Wadi Dana and Wadi Um Ghadah (Bir Madkour) ${ }^{[9]}$. The manganese in Wadi Um Ghadah is hosted within the bedded arkosic sandstone Lower Cambrian Saleb Formation, while the manganese of Wadi Dana occurs mainly within the Middle Cambrian Burj Formation, Numeric member composed of dolomite, limestone and shale (Fig. 1). Both deposits occur in three zones arranged from bottom to top: the primary sedimentary ore; the supergene stage, and finally the epigenetic stage ${ }^{[11]}$. Each stage has its own chemical and mineralogical characteristics.

Problem statements: This study is concerned with the Wadi Dana occurrence and mainly with the upper epigenic horizons stage. Coronadite is confined to this particular horizon, which shows higher $\mathrm{Pb}$ concentrations. These high $\mathrm{Pb}$ concentrations of the Burj Formation at Wadi Khaled and Wadi Mahjoob was the main reason for further investigations. El-Hasan $e t$ al. ${ }^{[11]}$ reported higher $\mathrm{Ba}, \mathrm{Pb}$ and $\mathrm{Zn}$ values within two manganese ore samples from Wadi Khaled. Moreover, coronadite was mentioned in the assemblage of the Timna manganese deposit, Israel ${ }^{[13,14]}$.

The mineralogical analysis results confirmed the presence of coronadite within this horizon. This mineral phase was identified for the first time as a major mineral phase within the Jordanian manganese deposits. In the study area, the mineral was identified at two sites: in Wadi Khaled in the west and in Wadi Mahjoob in the east. It is confined to the upper part of these profiles represents the Middle Cambrian Burj Formation (Figs. 1 and 2). The presence of coronadite is important to understand the genesis of the mineral paragenesis within the Cambrian manganese deposits as

Corresponding Author: Ahmad Al-Malabeh, Department of Earth and Environmental Sciences, Hashemite University, Zarqa 13115, P. O. Box 150459, Jordan 


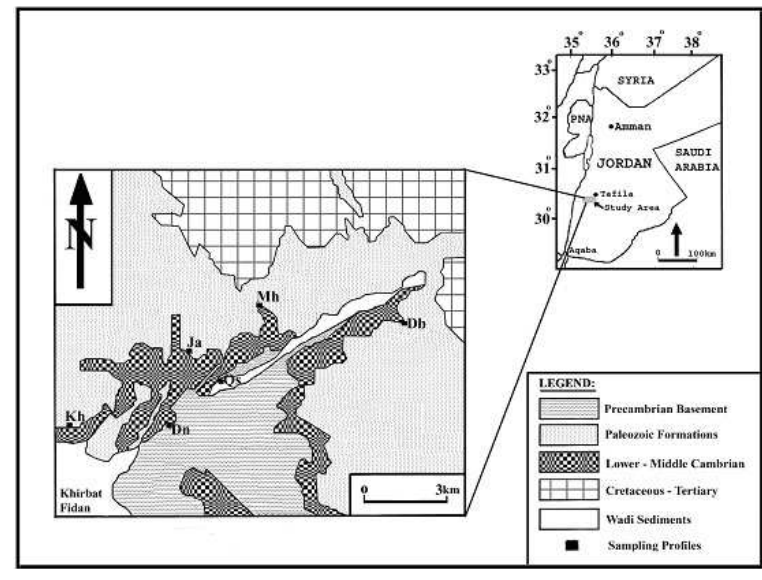

Fig. 1: Location and geological map of the Wadi Dana, showing the studied profiles Wadi Khaled $(\mathrm{Kh})$, and Wadi mahjoob $(\mathrm{Mh})^{[11]}$

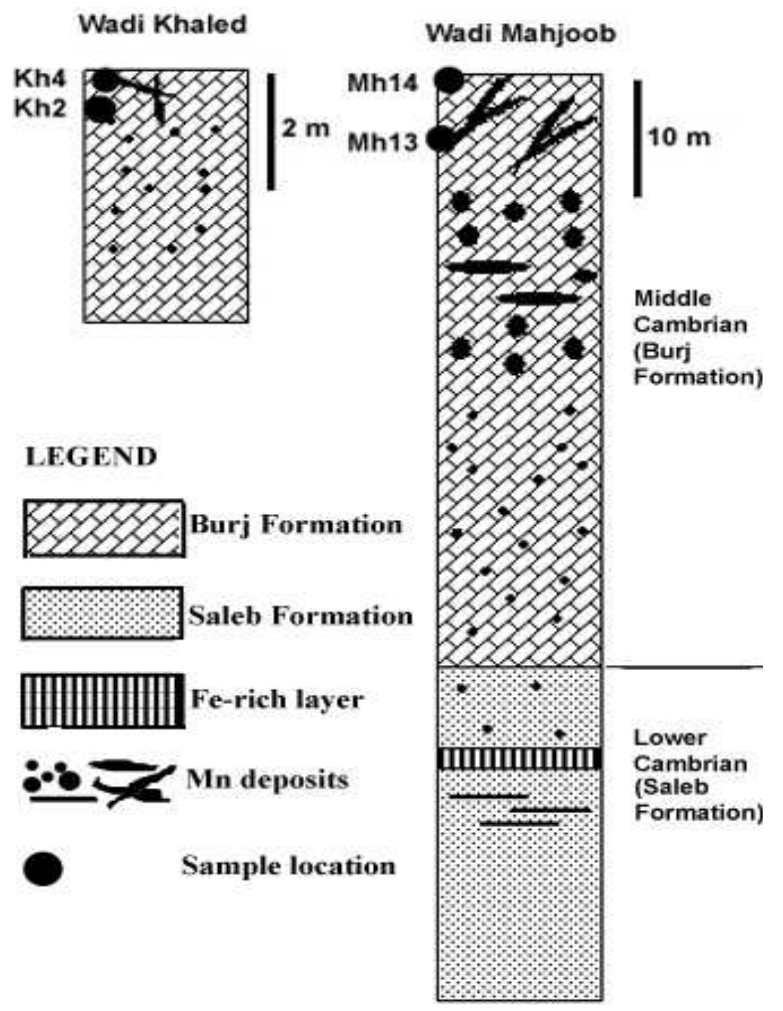

Fig. 2: Columnar section of the studied profiles showing the location of the investigated samples

discussed first by ${ }^{[11,12]}$ in more detail. Therefore, the mineralogy, chemistry and petro-genesis of this coronadite were reported. In addition, similarities and differences between the sites and other coronadite mineralizations in the region were investigated.
Geologic setting: The coronadite-hosting Burj Formation is underlain by the lower Cambrian Saleb Formation, (Fig. 2). The Burj Formation is a succession of thin layers of sandstone, dolomitic sandstone - sandy dolomite and red shale layers. The thickness is changing along the course of Wadi Dana ranging from 25-50 m, due to the irregular Precambrian paleo-terrain. The lithology of Saleb Formation starts with a dolomitic layer at the bottom and then changes into arkosic sandstone faces with clay alternations. This profile was very rich in manganese that occurs as thin bands, concretions, irregular bodies and as cross cutting veins at the top of the formation.

The varying thickness is accompanied by lateral lithological changes. This is visible specifically within the coronadite-hosting horizon, which consists of thin alternations of fine-grained sandstone with black claystone and carbonaceous layers in the west (Wadi Khaled). This horizon is only $4 \mathrm{~m}$ thick, divided into three parts. These are from bottom to top: (i) $1 \mathrm{~m}$ thick fine-grained sandstone with very thin alternations of clay, followed by (ii) $2 \mathrm{~m}$ thick very thin alternations of varve-like carbonaceous sandstone, with black claystone and siltstone. Mineral determination confirms the presence of a cryptocrystalline fluor-apatite as one of the main mineral constituents of this layer. Finally, the sequence is overlain by (iii) $1 \mathrm{~m}$ of massive, hard sandstone cemented by manganese minerals and secondary copper mineral (Chrysocolla) encrustations.

Wadi Mahjoob is located $4 \mathrm{~km}$ east of Wadi Jamal (Fig. 1). The Saleb Formation starts with $4 \mathrm{~m}$ basal conglomerate, followed by $25 \mathrm{~m}$ thick massive, varycolored, cross-bedded, arkosic sandstone. Some Mn mineralizations were found in this formation disseminated in the sandstone layers, in addition to thin, mineralized beds. Above the Saleb Formation the $40 \mathrm{~m}$ thick Burj Formation starts with dolomite interbedded by thin clay layers, followed by a succession of fine- to medium-grained sandstone, rose-brown colour and massive dolomite-dolomitic sandstone, with thin claystone intercalations. The upper part is a sandy facies and comprises the main ore horizon. It is intercalated with red claystone layers overlain by the Upper Cambrian sandstone Umm Ishrin Formation. The manganese in this profile occurs as bands, lenses, irregular bodies and concretions. In the upper portion $\mathrm{Mn}$ is filling the joints and forms stock-work veins.

\section{MATERIALS AND METHODS}

The studied samples have been collected from the horizons with the higher concentrations of $\mathrm{Pb}$ among the all studied ore samples from Wadi Dana profiles. 
They consist of four samples two from Wadi Khaled (Kh2 and Kh4) and two from Wadi Majoob (Mh13 and Mh14). The samples were analyzed for their bulk composition using XRF machine (RIGAKU model 3270). The operation conditions were: tube voltage 50 $\mathrm{kV}$ and tube current $50 \mathrm{~mA}$. The mineral identification was carried out using XRD micro-diffract meter machine with $\mathrm{CuK} \alpha$ radiation. The samples were studied under the microscope and undergone SEM analysis using the machine (SEM-EDS - JOEL - JSM 5400).

The quantitative mineral chemistry was carried out using the EPMA (JOEL-JXA 8621) EPMA Superprobe. The microprobe analytical conditions were $1 \times 10^{-8} \mathrm{~mA}$, 25-50 nA specimen current potential, 10 second integration time and $20 \mathrm{kV}$ acceleration potential, the SPI mineral standards were used for the calibration process

\section{RESULTS AND DISCUSSION}

Petrography: The coronadite found within the profiles of Wadi Khaled occur as secondary veinlets associated within the secondary chrysocolla and apatite, as well as, thin laminations alternating with apatite and siltstone layers (Fig. 3). The second profile of Wadi Mahjoob is located about $14 \mathrm{~km}$ to the east of Wadi Khaled. The coronadite-bearing horizon is the upper layers, where the coronadite is confined to these veinlets (Fig. 4).

Frondel, C. and E. Heinrich ${ }^{[15]}$ has described the coronadite in polish sections as rhythmic structures alternating with cryptomelane, psilomelane. Moreover, it belongs to tetragonal system and its XRD prime at $3.10 \AA$ (100). Moreover, the qualitative SEM photographs and chemical charts results for samples from both studied profiles reveal obviously the presence of coronadite as the peaks of $\mathrm{Mn}$ and $\mathrm{Pb}$ beside small peaks of $\mathrm{Ba}$ are evident as secondary veinlets (Fig. 5) and as curved alternating lamellae as in (Fig. 6). Furthermore, the lithology of the studied profiles is similar to Hakalil Formation, Nimra Formation, Nehustan Formation and Mikhrot Formation (from the bottom to the top) of Timna manganese outcrop at southern Israel ${ }^{[12,15-18]}$.

Geochemistry of the host rocks: The EPMA analysis has shown high $\mathrm{Pb}$ concentrations within the upper mineralized horizons (up to 8\%) (Table 1). The SEM, XRD and EPMA results confirmed the presence of coronadite. Previously high $\mathrm{Pb}$ and $\mathrm{Ba}$ concentrations were reported by ${ }^{[12]}$. He gave the following concentrations $(5.4,0.6,0.7$ and $0.8 \%)$ for $\mathrm{MnO}, \mathrm{Cu}$, $\mathrm{Ba}$ and $\mathrm{Pb}$, respectively for one sample from Wadi Khaled.

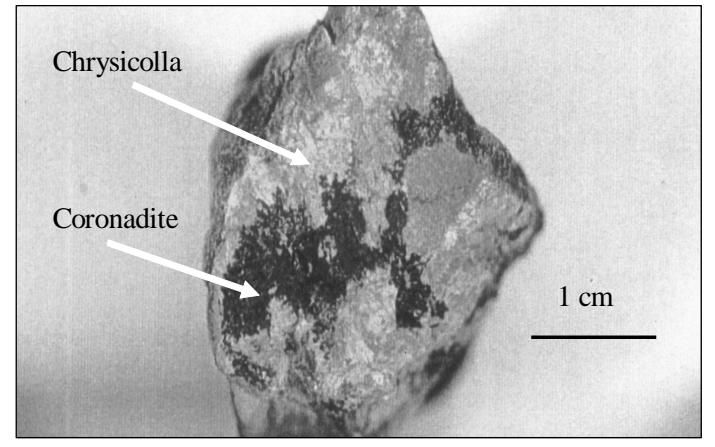

Fig. 3: Hand specimen from Wadi Khaled showing the coronadite veins (black) intruded the chrysicolla (Green)

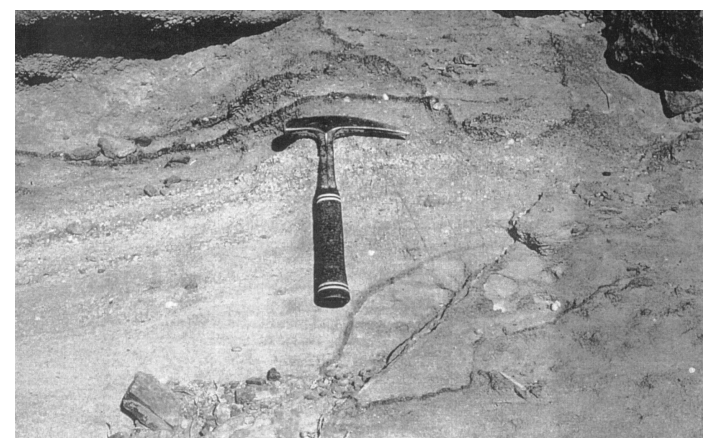

Fig. 4: Field photograph showing the stock-work veins that contains coronadite containing manganese veins at the upper part of Burj formation at Wadi Majoob profile ${ }^{[9]}$

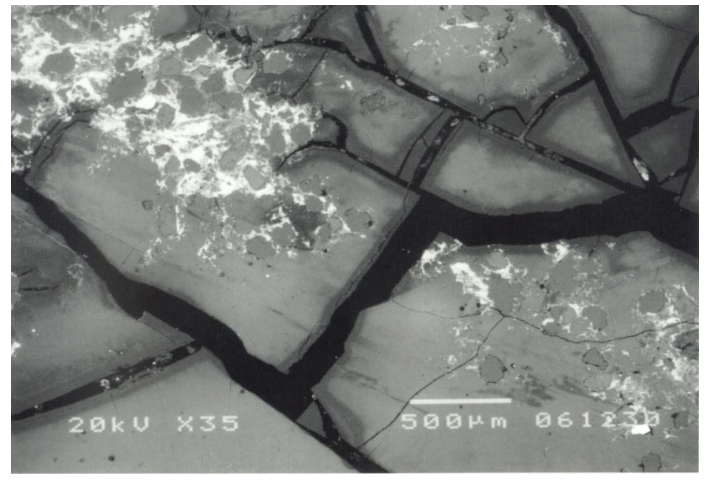

Fig. 5: SEM photo showing the epigenetic coronadite veinlets inside the chrysicolla, down is the quantitative SEM chart confirming the presence of coronadite

In spit of this high $\mathrm{Pb}$ content, coronadite was not detected at that time, which might be due to the lack of the instruments. 
Am. J. Applied Sci., 6 (4): 576-581, 2009
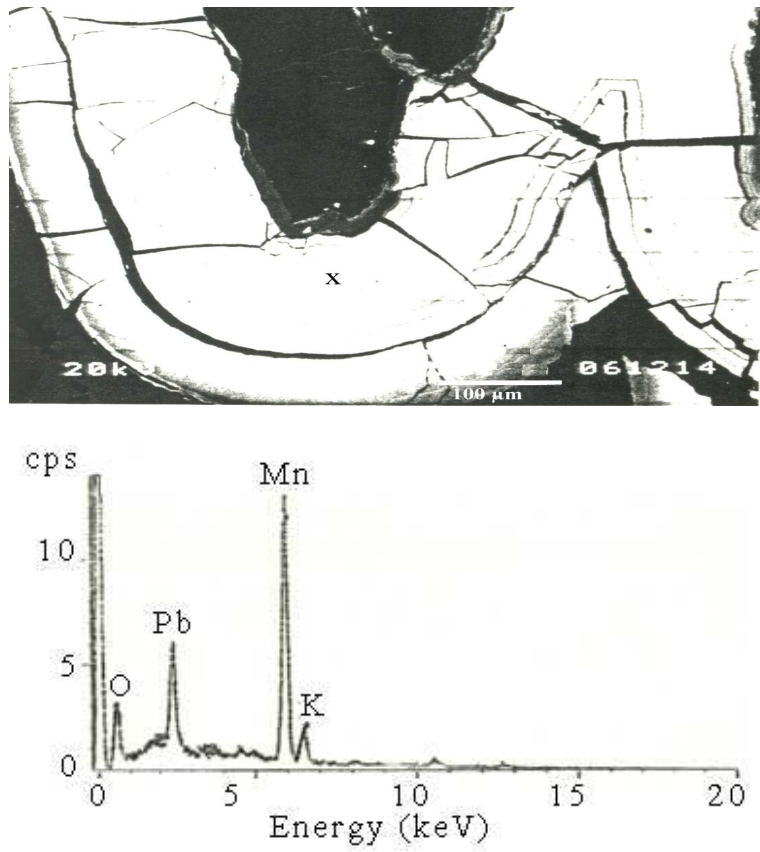

Fig. 6: SEM photo (Magn. X 150) of coronadite phase in the veins of Fig. 4 showing the curved lamellae texture; down is SEM chart showing the quantitative composition of the above texture at the point $(\mathrm{x})$

Table 1: Average of 15 EPMA analytical results for each studied sample. All in wt $\%$

\begin{tabular}{lrrlr}
\hline & \multicolumn{1}{c}{ Kh2 } & \multicolumn{1}{c}{ Kh4 } & Mh13 & \multicolumn{1}{c}{ Mh14 } \\
\hline $\mathrm{Mn}$ & $33.28 \pm 4.68$ & $31.63 \pm 7.29$ & $39.38 \pm 4.13$ & $46.31 \pm 6.30$ \\
$\mathrm{Fe}$ & $5.16 \pm 2.59$ & $0.81 \pm 0.56$ & $0.3 \pm 0.2$ & $0.17 \pm 0.07$ \\
$\mathrm{~K}$ & $0.64 \pm 0.55$ & $0.75 \pm 0.26$ & $0.21 \pm 0.05$ & $2.24 \pm 0.97$ \\
$\mathrm{Ba}$ & $3.98 \pm 1.14$ & $4.98 \pm 0.65$ & $4.79 \pm 1.14$ & $4.48 \pm 1.56$ \\
$\mathrm{~Pb}$ & $9.82 \pm 3.77$ & $3.87 \pm 0.83$ & $10.8 \pm 2.22$ & $3.26 \pm 1.08$ \\
\hline
\end{tabular}

The XRF analysis of whole rock the was carried out on samples from all Wadi Dana mineralized areas, the results shows that among 43 ore sample there are 4 samples that contain high $\mathrm{Pb}$ concentration. These 4 samples belong to Wadi Khaled and Wadi Mahjoob profiles that were mentioned in the analytical section. Bar-Matthews, M. ${ }^{[13]}$ have used the $\mathrm{Pb}$ plus Fe versus Mn discriminatory plot in order to discriminate between the various types of Timna Mn ore. However, when the discriminatory diagram is applied on the studied samples. It can be seen that the sample have nearly the same ore types (Fig. 7). Nevertheless, the studied samples were plotted within the epigenetic field or Btype after ${ }^{[13]}$ because of their high $\mathrm{Pb}$ contents. Moreover, the same samples were found to bear relatively higher $\mathrm{Zn}$ concentrations, therefore, they were found to scatter within the field of dubhite ${ }^{[11]}$.

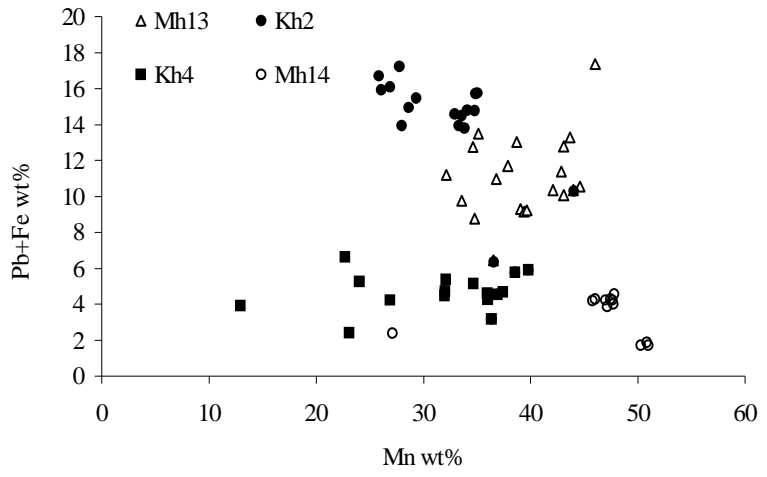

Fig. 7: Scatter diagram of studied samples showing clear variation in their $\mathrm{Pb}$ and $\mathrm{Mn}$ concentrations

Table 2: A comparison between the Pb-enriched manganese samples from Wadi Dana and hollandite-coronadite solid solution from Timna Mn deposits/ south Israel. All in wt\% only Zn in $\mathrm{ppm}$

\begin{tabular}{llllll}
\hline & 1 & 2 & 3 & 4 & 5 \\
\hline $\mathrm{Mn}$ & $18.74-44.02$ & $22.67-39.8$ & $32.13-46.03$ & $45.75-50.99$ & $30-52$ \\
$\mathrm{Ba}$ & $1.89-3.68$ & $3.9-5.83$ & $2.16-6.16$ & $2.76-6.91$ & $2-10$ \\
$\mathrm{~Pb}$ & $5.86-13.5$ & $2.19-5.48$ & $6.3-16.94$ & $1.6-4.35$ & $2-8$ \\
$\mathrm{Cu}$ & $1.27-5.77$ & $2.91-3.83$ & & $1.55-1.92$ & $1-3$ \\
$\mathrm{Fe}$ & $3.48-8.38$ & $0.44-4.94$ & $0.25-2.0$ & $0.14-0.56$ & $0.2-2.5$ \\
$\mathrm{~K}$ & $0.24-8.38$ & $0.46-2.16$ & $0.22-0.6$ & $1.13-3.74$ & $0.07-1$ \\
$\mathrm{Zn}$ & $723-2330$ & $560-2030$ & n.d. & n.d. & $2000-5000$ \\
\hline
\end{tabular}

(1) Kh2, (2) Kh4, (3) Mh13, (4) Mh14 and (5) Hollandite-Coronadite solid solution (after Bar-Matthews, 1987)

Nicholson, K. ${ }^{[5]}$ was the first to introduce the term dubhite that described the supergene terrestrial oxides formed by weathering of $\mathrm{Mn}$ rich sequences. This result is in consistence with the results given by ${ }^{[19]}$,in which he reported a cryptomelnae-hollandite-coronadite series in Vani manganese deposits, Milos, in Greece to contain high concentrations $\mathrm{K}, \mathrm{Ba}, \mathrm{Pb}$ and $\mathrm{Zn}$. Furthermore, this comparison shows the different behavior and mode of formation between $\mathrm{Fe}$ and $\mathrm{Pb}$. On one hand, $\mathrm{Fe}$ is enriched in the samples of Wadi Khaled and decreases toward the east the samples of Wadi Mahjoob. On the other hand, $\mathrm{Pb}$ shows a vertical or stratiform mode of occurrence. The behavior of Fe and $\mathrm{Pb}$ and their lateral spreading might be attributed to parameters of the environment such as Eh and $\mathrm{pH}^{[20,14]}$.

Mineral chemistry and genesis: Coronadite was described as $\mathrm{Pb}-\mathrm{Mn}$ oxide of variable composition ${ }^{[21]}$. However, the EPMA obtained data in Table 2 shows that the studied samples resemble those of hollanditecoronadite solid solution mentioned by ${ }^{[13]}$. Moreover, when comparing these analytical results with coronadite of ${ }^{[2]}$ (Table 3), it is obvious that studied samples cannot 
Am. J. Applied Sci., 6 (4): 576-581, 2009

Table 3: Selected EPMA data form the studied samples compared with coronadite analysis after ${ }^{[2]}$

\begin{tabular}{|c|c|c|c|c|c|}
\hline & \multicolumn{2}{|c|}{ Coronadite* } & \multirow[b]{2}{*}{ Cryptomelane } & \multirow[b]{2}{*}{ e Psilomelane } & \multirow[b]{2}{*}{ Pyrolusite } \\
\hline & 1 & 2 & & & \\
\hline$\overline{\mathrm{Mn}}$ & 43.94 & 43.88 & 56.180 & 50.5900 & 54.170 \\
\hline $\mathrm{Ba}$ & n.d & 0.21 & 0.900 & 13.5600 & 2.470 \\
\hline $\mathrm{Pb}$ & 26.37 & 24.55 & 0.004 & 0.0005 & 0.050 \\
\hline $\mathrm{Cu}$ & 0.04 & 0.11 & 0.710 & 0.6750 & 1.640 \\
\hline $\mathrm{Fe}$ & 0.39 & .21 & 0.051 & 0.0400 & 0.037 \\
\hline $\mathrm{K}$ & n.d & n.d & 4.280 & 0.1090 & 2.830 \\
\hline $\mathrm{Zn}$ & 0.08 & n.d. & 6760.000 & 1870.0000 & n.d. \\
\hline
\end{tabular}
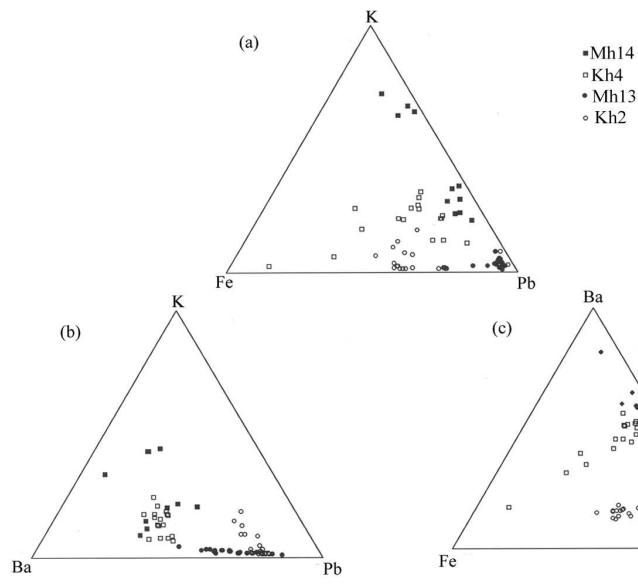

- Mh13

$\circ \mathrm{Kh} 2$

Fig. 8: Ternary diagram for the studied samples showing the variation in $\mathrm{Ba}, \mathrm{Fe}, \mathrm{K}$ and $\mathrm{Pb}$ within coronadite composition

be considered as pure coronadite but more likely a version of solid solution type.

The ternary plots of obtained values of $\mathrm{Ba}, \mathrm{K}, \mathrm{Fe}$ and $\mathrm{Pb}$ show clearly that there are no pure coronadite phase but rather hollandite-coronadite and cryptomelane-coronadite solid solutions mineral type phases (Fig. 8). This observation would clearly indicate the epigenetic mode of formation of the mineral, which is in agreement with field and petrography findings. From the EPMA obtained data the formula of coronadite was recalculated. It is been found as follows:

$$
\begin{gathered}
\left(\mathrm{Ba}_{(0.03-1.06)} \mathrm{K}_{(0.58-1.52)} \mathrm{Pb}_{(0.13-0.4)}\right)\left(\mathrm{Cu}_{(0.01-0.26)}\right. \\
\left.\mathrm{Fe}_{(0.02-0.28)} \mathrm{Mn}_{(5.47-7.67)}\right) \mathrm{O}_{16} \cdot \mathrm{xH}_{2} \mathrm{O}
\end{gathered}
$$

The upper position of coronadite-containing horizon and the nature of ore types, beside the microscopic and mineral chemistry of the solid solution phases all together would indicate the epigenetic nature of the forming solution. These four samples were found to belong to dubhites ore type. Such ore type is usually formed by lateralization process, which might accompany with descending meteoric water. Mineral of cryptomelane group are varied widely over short distance due to the strong influence of local variation in water chemistry ${ }^{[22]}$. This lateralization process affected the upper manganese supergene ores causing the formation of these $\mathrm{Pb}$-rich solutions. Many previous studies $^{[5,6,21]}$, have indicated the epigenetic nature of coronadite. However, in our case it's obvious that it is not pure coronadite phase but cryptomelane, psilomelane and hollandite-corondite solid solution phases. Such solid solution is an additional evidence of epigenetic mode of formation.

\section{CONCLUSION}

Mineral chemistry was shown an appreciable variation in $\mathrm{Mn}, \mathrm{Pb}, \mathrm{Fe}, \mathrm{K}$ and $\mathrm{Ba}$ contents in the coronadite of the studied samples. The petrography and geochemistry of the coronadite bearing samples reveals the epigenetic mode of formation. The $\mathrm{Pb}$ was found to increase downward in the two sites in spite of the wide lateral distance between them. Meanwhile, Fe shows almost horizontal trend, where higher Fe at the west and it decreases toward the east. This might be attributed to the nature, direction, time, as well as the mechanism of both $\mathrm{Fe}$ and $\mathrm{Pb}$ bearing solutions. The mineralogical and EPMA analysis revealed the presence of hollandite, cryptomelane and psilomelane-coronadite solid solution. The mineral chemistry of coronadite reveals a variation in the coronadite chemistry that is better indicated from the recalculated formula $\left[\left(\mathrm{Ba}_{(0.03-1.06)}\right.\right.$ $\left.\mathrm{K}_{(0.58-1.52)} \mathrm{Pb}_{(0.13-0.4)}\right)\left(\mathrm{Cu}_{(0.01-0.26)} \mathrm{Fe}_{(0.02-0.28)} \mathrm{Mn}_{(5.47-7.67)}\right)$ $\mathrm{O}_{16} \cdot \mathrm{xH}_{2} \mathrm{O}$ ]. The Coronadite outcrop at Timna manganese deposits bears many mineralogical and geochemical similarities to that found at the studied Wadi Dana area.

\section{ACKNOWLEDGMENT}

The authors would like to thank the Mr. Nishida from the analytical center/ university of Tsukuba for his help during the analysis of the samples. As well thanks are due to Dr. Hatta from the ministry of Agriculture laboratories-Tsukuba-Japan for his helping us chemical analysis. Our deep thanks also to Dr. K. Kumoro from the Institute of Geoscience-Tsukuba Univ., Japan and Prof. S. Kempe of Darmstadt Univ., Germany for their valuable discussions. 


\section{REFERENCES}

1. Hewett, D., 1971. Coronadite-modes of occurrence and origin. Econ. Geol., 66: 164-177. DOI: 10.2113/gsecongeo.66.1.164.

2. Frenzel, G., 1980. The manganese ore minerals. E. Sch. Verl. Stuttgart, 1: 25-158.

3. The In, J., 1992. Paleogeography and geochemistry of the cenomano-turonian formations in the manganese district of Imini (Morocco) and their relation to ore deposition. Ore. Geol. Rev., 5: 257-291.

4. Bricker, O., 1965. Some stability relations in the system $\mathrm{Mn}-\mathrm{O} 2-\mathrm{H}_{2} \mathrm{O}$ at $25^{\circ} \mathrm{C}$ and one atmosphere total pressure. Am. Mineral., 50: 1296-1354.

5. Nicholson, K., 1992. Contrasting mineralogicalgeochemical signature of manganese oxides: Guides to metallogenesis. Econ. Geol., 87: 1253-1264. http://knicholson.netfirms.com/pubs.html.

6. Ehrlich, S., Y. Harlavan, M. Bar-Mathews and L. Halicz, 2004. Lead and Uranium isotopic behavior in diagenetic manganese nodules, Timna Basin, Israel, determined by MC-ICP-MS. Applied Geochem., 19: 1927-1936. DOI: 10.1016/J.APGEOCHEM.2004.05.005.

7. Lindgreen, W. and W. Hillebrand, 1904. Minerals from the clifton-morenci District, Arizona. Am. J. Sci., 18: 448-460.

8. Orcel, M., 1942. La coronadite et le mineral qui la referme dans les gites de manganese de l'Imini Sud Marocian. Bull. Soc. Francaise Mineral. Crist., 65: 71-114.

9. El-Hasan, T., A. Al-Malabah, Y. Kajiwara and K. Komuro, 2001. Geochemical characteristics of the Cambrian manganese deposits of central Wadi Araba, South Jordan. Iraqi J. Sci., 42A: 1-39.

10. El-Hasan, T., A. Al-Malabeh, Y. Kajiwara and K. Komuro, 2001. Petrology, Mineralogy and genesis of Wadi Dana cambrian manganese deposit, central Wadi Araba region, Jordan. Qatar Univ. Sci. J., 21: 101-117.

11. El-Hasan, T., A. Al-Malabeh and K. Komuro, 2008. Rare earth elements geochemistry of the cambrian shallow marine manganese deposit at Wadi Dana, South Jordan. Jordan J. Earth Environ. Sci., 1: 33-40.

12. Khoury, H., 1986. On the origin of stratabound copper-manganese deposits in Wadi Araba, Jordan. Dirasat. Amman, 13: 227-247.
13. Bar-Matthews, M., 1987. The genesis of uranium in manganese and phosphorite asseblages, Timna Basin, Israel. Geol. Mag., 124: 211-229. http://geolmag.geoscienceworld.org/cgi/content/ab stract/124/3/211.

14. Bar-Matthews, M. and A. Matthews, 1990. Chemical and stable isotope fractionation in manganese oxide-phosphorite mineralization, Timna Valley, Israel. Geol. Mag., 127: 1-12. http://geolmag.geoscienceworld.org/cgi/content/ab stract/127/1/1.

15. Frondel, C. and E. Heinrich, 1942. New data on hetaerolite, hydrohetaerolite, coronadite and hollandite. Am. Miner, 27: 48-56. http://www.bcin.ca/Interface/openbcin.cgi?submit= submit\&Chinkey $=34274$.

16. Segev, A., 1984. Lithostratigraphy and paleogeography of the marine Cambrian in southern Israel and southwestern Jordan, Israel J. Earth $\quad$ Sci., 33: 26-33. http://cat.inist.fr/?aModele=afficheN\&cpsidt=9683087.

17. Segev, A.,1987. The age of the latest precambrian volcanism in southern Israel, northeast Sinai and southwest Jordan-a reevaluation: Precambrian Res., 36: 277-285.

18. Segev, A. and E. Sass, 1992. Copper-enriched syngentic dolostones as a Source for epigenetic copper mineralization in sandstones and shales (Timna, Israel). Geological Assoc. Canada, Special Paper, 36: 647-658.

19. Liakopoulos, A., G. Glasby, C. Papavassiliou and J. Boulegue, 2001. Nature and origin of the vani manganese deposit, Milos, Greece: An overview. Ore Geol. Rev., 18: 181-209. DOI: 10.1016/S01691368(01)00029-4.

20. Cronan, D., A. Jonhson and R. Hodkinson, 1997. Hydrothermal fluids may offer clues about impending volcanic eruptions. EOS, Transavt., 78: 341-345.

http://cat.inist.fr/?aModele $=$ afficheN\&cpsidt $=10265847$

21. Bystrom. A. and A. Bystrom, 1950. The crystal structure of hollandite, the related manganese oxide minerals and $\alpha-\mathrm{MnO}_{2}$. Acta Crysi., 3: 146-154. http://www.bcin.ca/Interface/openbcin.cgi?submit= submit\&Chinkey $=34269$.

22. Carlos, B., S. Chipera, D. Bish and S. Craven, 1993. Fracture-lining manganese oxide minerals in silicic tuff, Yucca mountain, Nevada, USA. Chem. Geol., 107 : 47-69. http://cat.inist.fr/?aModele=afficheN\&cpsidt=4811840 